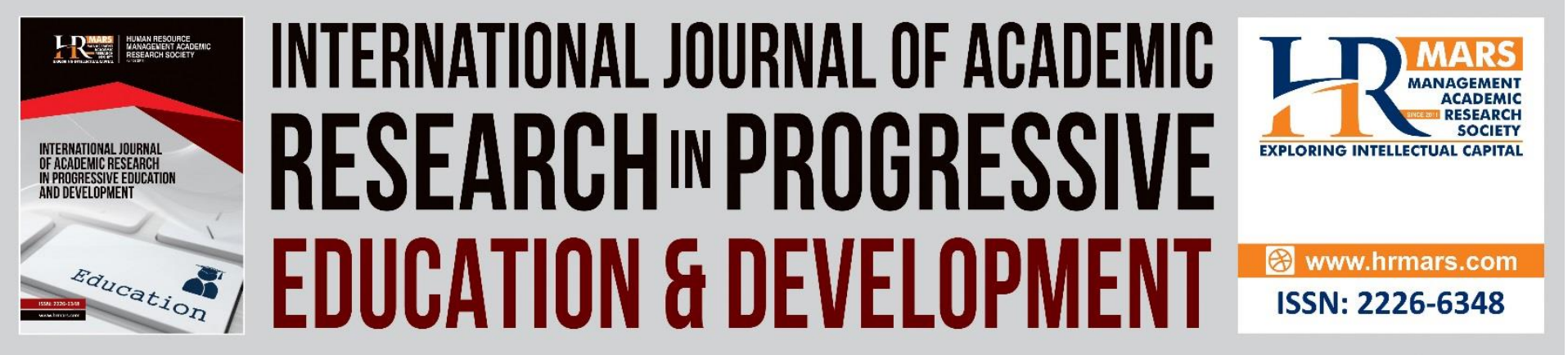

\title{
Analysis of Waqf Land Property Development of Penang State Islamic Religious Council (MAINPP) Based on Islamic Work Ethics (IWE)
}

Marina Abu Bakar, Sukriah Ismail, Che Zuina Ismail, Noor Asyimah Ramli

To Link this Article: http://dx.doi.org/10.6007/IJARPED/v10-i4/11876 DOI:10.6007/IJARPED/v10-i4/11876

Received: 11 October 2021, Revised: 12 November 2021, Accepted: 25 November 2021

Published Online: 20 December 2021

In-Text Citation: (Bakar et al., 2021)

To Cite this Article: Bakar, M. A., Ismail, S., Ismail, C. Z., \& Ramli, N. A. (2021). Analysis of Waqf Land Property Development of Penang State Islamic Religious Council (MAINPP) Based on Islamic Work Ethics (IWE). International Journal of Academic Research in Progressive Education and Development, 10(4), 196-217.

Copyright: (C) 2021 The Author(s)

Published by Human Resource Management Academic Research Society (www.hrmars.com)

This article is published under the Creative Commons Attribution (CC BY 4.0) license. Anyone may reproduce, distribute, translate and create derivative works of this article (for both commercial and non-commercial purposes), subject to full attribution to the original publication and authors. The full terms of this license may be seen at: http://creativecommons.org/licences/by/4.0/legalcode

Vol. 10(4) 2021, Pg. 196 - 217

http://hrmars.com/index.php/pages/detail/IJARPED

JOURNAL HOMEPAGE

Full Terms \& Conditions of access and use can be found at http://hrmars.com/index.php/pages/detail/publication-ethics 




\title{
Analysis of Waqf Land Property Development of Penang State Islamic Religious Council (MAINPP) Based on Islamic Work Ethics (IWE)
}

\section{Marina Abu Bakar ${ }^{1}$, Sukriah Ismail ${ }^{2}$, Che Zuina Ismail ${ }^{3}$, Noor Asyimah Ramli ${ }^{4}$}

${ }^{1}$ Kulliyyah of Shariah and Law, Sultan Abdul Halim Mu'adzam Shah International Islamic University (UniSHAMS), Kedah, Malaysia, ${ }^{2}$ Kulliyyah of Shariah and Law, Sultan Abdul Halim Mu'adzam Shah International Islamic University (UniSHAMS), Kedah, Malaysia, ${ }^{3}$ Academy of

Contemporary Islamic Studies (ACIS), Universiti Teknologi MARA (UiTM), Terengganu, Malaysia, ${ }^{4}$ Advocates \& Solicitors, High Court of Malaya, Shariah Lawyer, Noor Asyimah \& Associates, Penang, Malaysia.

Email: marinaabubakar@unishams.edu.my,sukriahismail@unishams.edu.my, chezu270@uitm.edu.my, noorasyimah@yahoo.com

\begin{abstract}
Penang State Islamic Religious Council (MAINPP) is the sole trustee of waqf property which is responsible for developing waqf property in the state of Penang as stipulated in the Islamic Religious Administration (State of Penang) Enactment 2004. In developing waqf properties, MAINPP must comply with various development processes in stages as appropriate in accordance with the law in the Malaysian context. Thus, compliance with the waqf property development process by Islamic institutions such as MAINPP is closely related to Islamic Work Ethics (IWE). The objective of this study is to examine the basic aspects of waqf property and the process of waqf property development in MAINPP, then analyze the development of waqf property in MAINPP according to Islamic Work Ethics (IWE). Data were collected through primary sources and secondary sources. The primary source involves semi-structured interviews with several MAINPP officials, while the secondary source involves data from figh books, books, journals and others. All study data were analyzed using content analysis method. The results of the study found that IWE can help MAINPP who is responsible as a manager in developing waqf properties in Penang. It is recommended that MAINPP practice IWE which contains the elements of intention, taqwa, justice (adil), sincerity (ikhlas), al-Itqan (awareness for self-improvement), ihsan, amanah, al-Sidq (truth), shura, patience, alMutabaqah (obedience), ruh al-Jama'ah (team spirit) and al-Riqabah (supervision) in developing waqf property in the state of Penang. This study is beneficial to the parties that administer waqf property such as MAINPP to take into account IWE throughout the waqf property development process is implemented.
\end{abstract}


DEVELOPMENT

Vol. 10, No. 4, 2021, E-ISSN: 2226-6348 @ 2021 HRMARS

Keywords: Development, Waqf Property, Penang Islamic Religious Council (MAINPP), Islamic Work Ethics (IWE)

\section{Introduction}

The waqf property development process in Malaysia has undergone various changes from time to time over a long period of time. In Penang, this is no exception. MAINPP as the sole trustee of waqf property in the state of Penang has worked proactively in developing the existing waqf lands. The success of waqf property development in Penang is evident in several areas in Penang. Among them, such as Kapitan Keling Waqf Land, Alimsah Waley Waqf Land, Lebuh Acheh Mosque Waqf Land and Lebuh Chulia Waqf Land. All these waqf lands are strategically located in the middle of Georgetown City and consist of rows of commercial buildings, namely gold shops, nasi kandar restaurants, travel agencies and licensed money changers hired by the Indian Muslim community (Roslan, 2017). Thus, this article aims to examine the basic aspects of waqf property and the process of waqf property development in MAINPP, then analyze the development of waqf property in MAINPP according to Islamic Work Ethics (IWE). This article was divided into three main parts, namely the introduction of real estate basics, MAINPP waqf real estate development and Islamic Work Ethics (IWE).

\section{Real Estate Introduction \\ Definition of Land and Land Property}

The land property industry is one of the important industries in determining the economic and social progress of a country. This is because, land is an important resource in economic and social development and if managed competently and efficiently, it will definitely produce maximum value and bring lucrative returns to the country itself. Therefore, every player in the land property industry must be wise in managing land property, especially those involving the sale, purchase, rental and transfer of land so that its use can be achieved to the maximum.

In Malaysia, the definition of land can be seen in Section 5, National Land Code Act (KTN) 1965, which provides that land includes several important components, including the earth's surface and all things that make up the earth's surface such as rocks and sand, soil below the earth's surface and all things contained therein such as mineral rocks, all plants and other natural products such as trees, all things attached to the earth whether above or below the surface of the earth and land covered with water as right to water. In addition, the term "land" is also known as "ad caelo usque ad centrum" in Latin, which means "from the air space to the centre of the earth". These terms clearly demonstrate that soil theory is to cover anything that is on the surface of the earth, the earth itself and anything that is beneath it to the bottom of the earth (Osman \& Shafie, 2006).

Meanwhile, land property includes land, buildings and resources on it. Therefore, any building or residential house erected, vacant land or open space as a car park, green areas around the city, grass crops or land for development and industry are also included in the category of real estate. What is interesting, the land property is unique because it is different from other commodities. The land property has certain privileges as described in Table 1: 
Table 1: Land Property Privileges Source: Osman \& Shafie (2006)

\begin{tabular}{|c|c|c|}
\hline No & Privileges & Description \\
\hline i. & Difference & Hetrogenous between one field of land with another field. \\
\hline ii. & Durable & $\begin{array}{l}\text { Land or site is permanent unless erosion occurs, transfer of } \\
\text { ownership or human activities such as road construction }\end{array}$ \\
\hline iii. & $\begin{array}{l}\text { Can cause a variety } \\
\text { of interests }\end{array}$ & Involves permanent interest, taxes, small taxes and others \\
\hline iv. & $\begin{array}{l}\text { High market price } \\
\text { or capital value }\end{array}$ & Market price or capital value is higher than other commodities \\
\hline v. & Control legislation & $\begin{array}{l}\text { Legislation in regulating property as it relates to ownership } \\
\text { and ownership, planning and development }\end{array}$ \\
\hline vi. & Limited offer & $\begin{array}{l}\text { The quantity of land cannot be increased unless the number } \\
\text { of office floors is changed or increased after obtaining } \\
\text { planning approval }\end{array}$ \\
\hline vii. & High demand & $\begin{array}{l}\text { Demand is higher than supply because the majority of society } \\
\text { needs land and houses }\end{array}$ \\
\hline viii. & $\begin{array}{l}\text { Investment } \\
\text { prospects }\end{array}$ & $\begin{array}{l}\text { Profitable because it involves the purchase of real estate for } \\
\text { investment such as rentals, residences that can be resold at a } \\
\text { high price }\end{array}$ \\
\hline ix. & $\begin{array}{l}\text { High management } \\
\text { costs }\end{array}$ & $\begin{array}{l}\text { Involves costs such as assessment tax and land tax, building } \\
\text { repair costs, rent collection and transfer costs, insurance and } \\
\text { fire and building own management costs. }\end{array}$ \\
\hline
\end{tabular}

\section{Land Property Characteristics}

Land Property is different from other commodities because it is an exclusive source of investment. In addition, it also has some differences in terms of management methods, value, importance, pricing and purchasing process. Land property features can be divided into several parts, namely physical condition features, institutional features, economic features and market features (Osman \& Shafie, 2006). All of these features can have an impact on the value of a real estate. The descriptions for each of these features are summarized as follows:

\section{i. Physical Condition Features}

Some of the unique features present on the real estate are durable, have a twist, are permanent and cannot be destroyed. The land property has an age that exceeds the life of the right holder despite being eroded. The land property is also not the same from one area to another due to differences in location and position that have different physical properties and landforms. The position of the land property is fixed and cannot be moved or relocated from one place to another. The location of the soil is fixed and heterogeneous. Another feature of land property is that it is indestructible. This is because all land components such as physical assets and objects that are in accordance with the law cannot be destroyed. However, property can be eroded, flooded or become obsolete. Nevertheless, the location and design of the land on the surface of the earth will often remain the same.

\section{ii. Institutional Features}

The institutional features of land property are property law, public regulations, local cultural customs and establishments or organizations. In the context of Malaysia, the applicable 
property law is the National Land Code Act (KTN) 1965 which was enacted by the Yang DiPertuan Agong with the advice and approval of the Dewan Negara and Dewan Rakyat. KTN aims to amend and consolidate the laws relating to land and land ownership with land ownership, registration of land title deeds and their division as well as revenue collection from certain states in Malaysia.

Public regulations such as zoning, development codes and land property tax assessments also have an impact on property values. In addition, local cultural customs also influence the development that will be carried out on the property. For example, development carried out in Penang needs to be adapted to the terrain of the island and take into account the culture, customs and practices of the local community. The use of land property is influenced by rules and restrictions imposed based on the scope set by an establishment or organization involved in the planning and administration of property in Malaysia. Among the institutions are the Department of Town Planning and Regional Development, the Malaysian Housing Developers Association, the Department of Health, the Ministry of Natural Resources and Environment and the Fire Department, the Land Survey Department and the Land Office. All these institutions are government bodies whose role is to ensure that property functions are used in the correct manner in accordance with the law in Malaysia.

\section{iii. Economic Features}

Among the economic features of the property include limited supply, fixed investment, renovations and situs. The supply of land property is limited as the quantity of land cannot be increased unless the floor of the building is added after obtaining approval. In fact, the sea can also be reclaimed and buildings erected on it. One more thing, land development involves a large investment in labour and capital. The value of land can increase or decrease due to development around it or changes due to the tastes of the people. Therefore, some considerations need to be done before the purchase and renovation process especially those involving long-term investment for the use of the land. Land renovation can be implemented through the addition of roads, recreational areas, construction of factories or business hubs. All these renovations further increase the value of the property and the surrounding community based on the economic concept that is the result of the impact of development on the value of land. Situs is the provision of a facility on land and this includes the influence of the provision on that land area. Situs serves as an interaction along with the use of around a piece of land. It can also be influenced by the surrounding economic conditions.

\section{iv. Market Features}

Land property has a different market than the capital and money markets. This is because land property is different in terms of value for each piece of land. There are several factors that influence the features of the real estate market, namely local competition, structured market and other factors. Locally, the position of the property is fixed. Therefore, the competition is specific. For example, the price of a two-storey bungalow house in Kuala Lumpur is not the same as the price in Penang or Kedah. In fact, if there is an oversupply of houses in Kajang, Selangor, it will not be able to cover the shortage of houses in Johor Bharu, Johor. Market performance in land property is sensitive to changes around it. In addition, the price for the real estate is also determined in consultation between the seller and the buyer or broker. In fact, in some situations, land property sale transactions are done privately and there is no organizational structure to manage them. This is in contrast to the capital and 
money markets, where prices in these markets can be determined by Bursa Malaysia. Other factors that affect land property are such as population, including population age, unemployment rate, marriage rate and family size, inflation, interest rates, development costs and risks.

\section{Waqf According to Islam}

The word waqf in Arabic comes from waqafa which means to withhold something. Withholding something meant here is withholding a property solely because of Allah SWT for the public interest (al-Ansari, t.t). There are various definitions of waqf that have been put forward by jurists such as (al-Qurtubi, 1980; al-Syarbini, 1933; Ibn 'Abidin, 1966). Al-Qurtubi says that waqf is to give out property and benefits to the path that is pleasing to Allah in order to get closer to Allah (al-Qurtubi, 1980). Al-Sharbini, on the other hand, argues that waqf is to withhold a property or item that can be utilized on the condition that it remains physically in accordance with the conditions allowed by Islamic law (al-Syarbini, 1933). On the other hand, Ibn 'Abidin explained waqf as holding a property on the terms of its owner and used for public benefit (Ibn 'Abidin, 1966). Based on the definitions of waqf, it can be concluded that waqf property in Islam must have seven specific features, namely; the property to be endowed must be clearly owned, can provide benefits, not of a type forbidden by Islamic law, is physically permanent, cannot be used other than what is required, for waqf that does not specify its use, then it can be used in accordance with Islamic law and results of waqf property can be used for general or specific benefits. Waqf is also a circumcision ritual that is strongly encouraged by Islam. Meanwhile, the pillars of waqf are divided into four, namely; waqf giver, waqf property, waqf recipient and ijab and qabul (sighah) (al-Khin, et al., 2003). Based on the concept of waqf in Islam as well, waqf property is considered to belong to Allah SWT absolutely. According to this principle, waqf property cannot be sold, bought, used as a gift or inheritance either by the waqf giver or the waqf recipient or beneficiary. Therefore, the use of this waqf property is handed over to the waqf recipient and managed according to the waqf giver's wishes.

\section{Waqf Land in Malaysia}

In Malaysia, KTN 1965 has clearly explained about two separate concepts of land, namely classification and category. In terms of land classification, land located in a state can be divided into two classes, namely; (i) land above the shoreline, and this land may be disposed of by the State Authority (PBN) by way of purchase of ownership or other than grant of ownership, (ii) the coastline and seabed, and this land may not be disposed of in any way. Then, some of the provisions contained in this classification can be divided into three types of land, namely State Land, Malay Reserve Land and Alienated Land. In terms of categories, there are four categories of land use, namely agriculture, trade, housing and industry. Waqf land in Malaysia is categorized as Owned Land. Registered title is a document that confirms title and cannot be denied or questioned. It is enshrined in Sections 89 and 340 KTN 1965. It is also conclusive evidence of a person's ownership of his land, including waqf land.

In terms of law, there are three methods of transfer of ownership of waqf land practiced by land administrators in Malaysia (Mahamood, 2001). First, waqf land that has been transferred, is registered under one title through Form 14A KTN at the Land Office. The Land Registrar will register the name of the State Islamic Religious Council (MAIN) as a legally valid transferee. Second, the waqf giver returns the land (surrender) to the government or PBN. This method is done by using Form 12A for the whole land and Form 12B for part of the 
land. The land that has been handed over will be fully owned by the government, while MAIN will reapply the land to the government and be registered under MAIN as the sole trustee of the waqf land. Third, through the application of MAIN for the purpose of vesting according to the law (statutory vesting) for waqf land as provided in Section 416C KTN. This method is done by making a letter to the Registrar of Title or Land Administrator. Confirmation of MAIN's name will be made on the title document of the waqf land. All waqf land registered through these three methods will remain the property of MAIN, final and non-transferable by MAIN.

In short, waqf land is land owned by an individual or a group of people who hand over ownership of the land for public use. Waqf land is usually used for religious purposes, education and any activities that benefit the public and become amal jariah for waqf givers. The administration of waqf land in the pre-independence era was managed by individuals or committees such as mosque committees before it was transferred and continues to be administered by MAIN throughout the states in Malaysia (Sayyin et al., 2006).

\section{MAINPP Waqf Property Development \\ Penang Islamic Religious Council (MAINPP)}

The management of waqf in Malaysia is placed under the religious authority of the states based on provision 3 (2) of the Federal Constitution which states that the Raja is the Head of Religion for the states that have a Raja, while the Yang Di-Pertuan Agong is the Head of Religion for the states- a state that has no Sultan or King. The State Islamic Religious Council (MAIN) was established to assist in advising DYMM Sultan on religious matters, including waqf. Legally, MAIN is the sole trustee of all waqf properties. This provision can ensure that there are no irregularities in the management of waqf property and the control and development of waqf property can be carried out in accordance with the concept of waqf and Islamic law from time to time.

As for the state of Penang, starting in 1905, the administration of waqf land was according to the British colonial system and managed by the Muslim and Hindu Endowments Board 1905 (MAHEB). In 1959, MAINPP was established through the Islamic Religious Administration Law Enactment 1959. The implication is that all waqf lands once administered by MAHEB were taken over by MAINPP in stages based on Section 89 (2), Islamic Religious Administration Law Enactment 1959. The entire process of acquisition of waqf land administration by MAINPP was successfully completed on 1 January 1967. Currently, all provisions related to waqf are contained in the Islamic Religious Administration (State of Penang) Enactment 2004. Meanwhile, in terms of waqf property development, Table 2 and 3 , shows the list of waqf land with projects that have been developed, under construction and in planning for the period 2010 to 2018 by Penang State Islamic Religious Council( MAINPP): 
Table 2: List of MAINPP Projects in Planning for Development (2010-2018) Source: MAINPP (2020)

\begin{tabular}{|c|c|c|c|c|}
\hline NO & PROJECT NAME & $\begin{array}{ll}\text { TYPE } & \text { OF } \\
\text { DEVELOPMENT } & \\
\end{array}$ & FINANCING & COST (RM) \\
\hline 1. & $\begin{array}{l}\text { Proposed development } \\
\text { on Lot } 1396 \text { \& } 1606 \\
\text { (Wakaf Sheikh Eusoff), } \\
\text { Section 5, Jalan Air Itam, } \\
\text { DTL, Penang }\end{array}$ & $\begin{array}{l}\text { Development of } \\
391 \text { units of low } \\
\text { medium cost } \\
\text { apartments, } 1305 \\
\text { units of medium } \\
\text { cost apartments, } 14 \\
\text { units of shops, } 56 \\
\text { units of office } \\
\text { shops, } 66 \text { units of } \\
\text { hawker centres, } \\
\text { suraus, halls, and } \\
\text { orphanages }\end{array}$ & $\begin{array}{l}\text { Joint venture with } \\
\text { Uda Sdn. Bhd. }\end{array}$ & 150 Million \\
\hline 2. & $\begin{array}{l}\text { Proposed development of } \\
\text { Kampung Dodol, Jalan } \\
\text { Perak, Jelutong, DTL }\end{array}$ & $\begin{array}{l}\text { Housing } \\
\text { development of } \\
1916 \text { apartment } \\
\text { units, multipurpose } \\
\text { hall, expansion of } \\
\text { mosque and } \\
\text { Sekolah Agama } \\
\text { Rakyat }\end{array}$ & $\begin{array}{lr}\text { Yayasan } & \text { Islam } \\
\text { Pulau } & \text { Pinang } \\
\text { (Pulau } & \text { Pinang } \\
\text { Islamic } & \\
\text { Foundation) }\end{array}$ & 470 Million \\
\hline 3. & $\begin{array}{l}\text { Proposed development of } \\
\text { Low Medium Cost } \\
\text { Housing on Lot PT 32, } \\
\text { Section 3, Bandar George } \\
\text { Town, DTL }\end{array}$ & $\begin{array}{l}\text { Housing } \\
\text { Development } 114 \\
\text { units (House of } \\
\text { Asnaf) }\end{array}$ & $\begin{array}{l}\text { MAINPP/Wakaf } \\
\text { Pulau Pinang Sdn. } \\
\text { Bhd. }\end{array}$ & 30 Million \\
\hline 4. & $\begin{array}{l}\text { Proposed construction on } \\
\text { Lot 496, Mukim 4, Bagan } \\
\text { Lalang, SPU }\end{array}$ & $\begin{array}{l}\text { Development of } \\
\text { house/shop units }\end{array}$ & $\begin{array}{l}\text { MAINPP/Wakaf } \\
\text { Pulau Pinang Sdn. } \\
\text { Bhd. }\end{array}$ & 25 Million \\
\hline 5. & $\begin{array}{l}\text { Proposed development } \\
\text { on Lot 208, Section 2, } \\
\text { Butterworth, SPU }\end{array}$ & $\begin{array}{l}\text { Construction of } 400 \\
\text { housing units }\end{array}$ & - & 50 Million \\
\hline
\end{tabular}


INTERNATIONAL JOURNAL OF ACADEMIC RESEARCH IN PROGRESSIVE EDUCATION AND

DEVELOPMENT

Vol. 10, No. 4, 2021, E-ISSN: 2226-6348 @ 2021 HRMARS

Table 3 List of MAINPP Projects in Planning for Development (2010-2018)

Source: MAINPP (2020)

\begin{tabular}{|c|c|c|c|c|}
\hline NO & PROJECT NAME & $\begin{array}{ll}\text { TYPE } & \text { OF } \\
\text { DEVELOPMENT }\end{array}$ & FINANCING & COST (RM) \\
\hline 1. & $\begin{array}{l}\text { Construction of Medium } \\
\text { Cost Apartments on Wakaf } \\
\text { Land Lot } 6247 \text { \& 6249, } \\
\text { Mukim 7, SPU }\end{array}$ & $\begin{array}{l}\text { Construction of } \\
\text { low-medium cost } \\
\text { apartments } 152 \\
\text { units of } 2 \text { blocks, } 8 \\
\text { and } 12 \text { floors }\end{array}$ & JAWHAR & 38 Million \\
\hline 2. & $\begin{array}{l}\text { Development on Lot 3117, } \\
252 \text { \& } 200 \text { (Taman Wakaf } \\
\text { Seetee Aisah Phase 2), } \\
\text { Mukim 4, Seberang Jaya, } \\
\text { SPT, Penang }\end{array}$ & 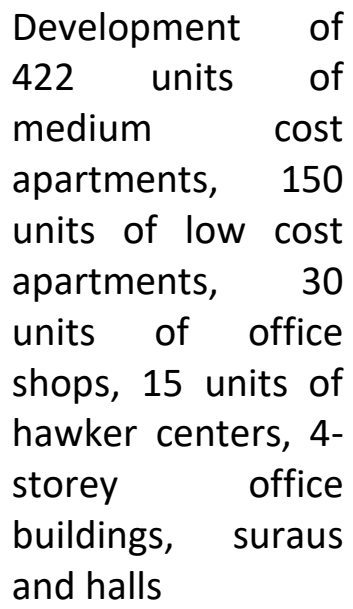 & $\begin{array}{l}\text { Joint venture } \\
\text { with Uda Sdn. } \\
\text { Bhd. }\end{array}$ & 120 Million \\
\hline
\end{tabular}

Table 4 List of Completed MAINPP Projects (2010-2018)

Source: MAINPP (2020)

\begin{tabular}{|c|c|c|c|c|}
\hline NO & $\begin{array}{l}\text { PROJECT NAME/YEAR } \\
\text { COMPLETED }\end{array}$ & TYPE OF DEVELOPMENT & FINANCING & COST (RM) \\
\hline 1. & $\begin{array}{l}\text { Lot } 247 \text { (Maahad Al- } \\
\text { Mashoor Al-Islami), } \\
\text { Jalan Sungai Nipah, } \\
\text { Mukim G, Balik Pulau, } \\
\text { DBD, Pulau Pinang- } \\
2011\end{array}$ & $\begin{array}{l}\text { Construction of } \\
\text { administrative blocks, } \\
\text { libraries, classrooms, } \\
\text { male/female } \\
\text { dormitories, dining halls } \\
\text { and STP }\end{array}$ & JAWHAR & 42 Million \\
\hline 2. & $\begin{array}{l}\text { Part of Lot 4811, } \\
\text { Mukim 7, Permatang } \\
\text { Tok Gelam, SPU, } \\
\text { Penang - December } \\
2013\end{array}$ & $\begin{array}{l}\text { Construction of Darul } \\
\text { Hidayah Complex which } \\
\text { includes } 1 \text { block of } 3 \\
\text { storey } \\
\text { dormitory/academic } \\
\text { building, } 1 \text { storey hall } \\
\text { and } 1 \text { storey surau }\end{array}$ & $\begin{array}{l}\text { MAINPP/Zakat } \\
\text { Pulau Pinang }\end{array}$ & 6.8 Million \\
\hline 3. & $\begin{array}{l}\text { Lot } 1444 \text { (Taman } \\
\text { Wakaf Seetee Aisah } \\
\text { Phase 1), Mukim 4, } \\
\text { Jalan Tun Hussein Onn, } \\
\text { Seberang Jaya, SPT, } \\
\text { Penang - February } \\
2013\end{array}$ & $\begin{array}{l}\text { Construction of } 76 \text { units } \\
\text { of } 2 \text {-storey terrace } \\
\text { houses and } 9 \text { units of } 3- \\
\text { storey shops }\end{array}$ & $\begin{array}{l}\text { Joint venture with } \\
\text { UDA Sdn, Bhd. }\end{array}$ & 21 Million \\
\hline
\end{tabular}


DEVELOPMENT

Vol. 10 , No. 4, 2021, E-ISSN: 2226-6348 @ 2021 HRMARS

\section{Waqf Property Development Concept by MAINPP}

There are several basic principles in the development of waqf property in MAINPP, namely that it cannot be sold, cannot be inherited and cannot be endowed. These principles are in line with the concept of waqf outlined by Islamic law. MAINPP also refers to the Sixteenth Fatwa issued by the Department of Islamic Development Malaysia (JAKIM) regarding the law of handing over part of waqf land to the authorities (JAKIM, 2000). In addition, in terms of practice, there are several principles of waqf land development practiced by MAINPP as follows (MAINPP, 2021):

i. Permanent Land owned by MAINPP as Trustee.

ii. Form 15A applies to Land Lease.

iii. Land may not be sold, pledged or mortgaged.

iv. MAINPP can grant leases for a lease period of 99 years to the lessee.

v. After the expiry of the lease, the land is returned to MAINPP.

vi. The Leaseholder can apply from MAINPP to extend the lease term after it expires. Meanwhile, for the property development concept carried out, MAINPP and Syarikat Wakaf Pulau Pinang Sdn. Bhd (WPPSB), a wholly-owned subsidiary of MAINPP, has entered into a joint venture with the developer to make a development project a success. This joint venture concept involves the division of roles, costs and profits between MAINPP and WPPSB with the developer. Table 5 is the concept of waqf property development by MAINPP:

Table 5 Waqf Property Development Concept ny MAINPP Source: MAINPP (2020)

\begin{tabular}{|c|c|c|}
\hline $\begin{array}{ll}\text { JOINT } & \text { VENTURE } \\
\text { CONCEPT } & \end{array}$ & MAINPP/WPPSB & DEVELOPER \\
\hline Roles & $\begin{array}{l}\text { - Provide waqf land to } \\
\text { be developed } \\
\text { - Assist in expediting the } \\
\text { procurement of } \\
\text { development } \\
\text { approvals through } \\
\text { liaison between } \\
\text { government agencies }\end{array}$ & $\begin{array}{l}\text { - Act as a developer to } \\
\text { develop waqf land } \\
\text { - Remove the entire cost } \\
\text { of development }\end{array}$ \\
\hline Cost Distribution & Current land value & Development cost \\
\hline Profit Sharing & $\begin{array}{l}\text { Current land value }+\% \\
\text { additional profit (depending } \\
\text { on project profit) }\end{array}$ & $\begin{array}{l}\text { Total sales revenue collection } \\
\text { minus return to MAINPP }\end{array}$ \\
\hline
\end{tabular}

\section{Implications of Waqf Property Development}

The development of waqf properties is very closely linked to social change and the framework of economic space needs in the community. Ultimately, this requirement is space for a city where there is a network of roads, utilities and additional structures. Among the implications involving property development are the breakdown of opponents of mergers, changes in property development and changes in land use as follows:

i. $\quad$ Breakdown of Opponents of Mergers

Fragmentation is the division of a large piece of land into smaller ones, while amalgamation is the amalgamation of land to produce a fully operational property. Subdivision involves 
smaller subdivisions such as for family housing, office buildings etc. and is done according to the rules of the area.

ii. Land Property Development Changes

Among the significant changes in land property development is a comfortable life through good facilities in various aspects such as communication networks, electricity and water facilities, garbage disposal and so on. In Penang, changes in land property development involving waqf are seen as significant in several locations such as Kapitan Keling Wakaf Land, Seetee Aishah Wakaf Land and Mohamed Hashim Wakaf Land. All the development carried out on these waqf lands has clearly succeeded in prospering the surrounding area (Ismail et al., 2021; Ismail et al., 2021).

iii. Land Use Changes

The waqf land that is developed can provide a return of money and value to MAINPP. For example, in Penang there are many waqf lands that have a high value and are located in strategic areas such as Haji Kassim Wakaf Land, Hashim Yahaya Wakaf Land and Kampung Dodol Wakaf Land which is estimated to have an area of 21 acres or 8.5 hectares. There are also some lands with high potential for development, but their use has not been optimized, namely Shaik Yusoff Wakaf Land with an area of 14 acres or 5.6 hectares and Wan Chik Ariffin Wakaf Land with an area of 0.9 acres or 0.4 hectares (Roslan, 2017). Clearly, the felling of forest and plantation areas to be used as housing areas and buildings on rented waqf land has proven successful in increasing the use, productivity and value of the land which can ultimately contribute to the socio-economic aspects of the Muslim community in Penang.

\section{Venue Selection}

MAINPP needs to assess the location of waqf land that is suitable for development. Normally, the selection will be made twice. The first result was the acquisition of a place where the collected data was studied by MAINPP on the potential for development. Meanwhile, the second decision involves the choice of place for the sale of projects that have been successfully developed. In making the selection and analysis of a place, several important elements need to be emphasized, namely place or location, comfort, shape and size, physical shape, facilities and services, usability of public services, cost and value.

For housing projects, the basic factor taken into account by MAINPP is position. An appropriate position is a position that is close to basic facilities and away from any contamination. Comfort is also a factor that is taken into account such as the convenience of commuting to public places and a harmonious environment. In addition, the size, shape and physical shape also play a role in the selection of waqf property development site. Terrain conditions, soil fertility, electricity and water service facilities, as well as cost or value also need to be commensurate with the development. High costs with low profits will usually be to the detriment of many parties.

In addition to housing, the commercial conditions that already exist in the development area will also be the determinants of the area to house trade. For commercial land to be developed, population and market analysis must be done by MAINPP before the development is implemented. Some other things that need to be considered also include communication network facilities, size, cost and value of the land property. As for industrial land, MAINPP must assess some basic things such as raw material facilities, labour, supply of components and the market for goods directly to consumers. In addition, the size and basic amenities such as electricity and water need to be taken into account. As with commercial 
property, the value and cost of industrial property must be consistent and commensurate with the profits to be made by MAINPP and the developer.

\section{Waqf Property Development Process by Stage by MAINPP}

The waqf property development process needs to go through various types of considerations that involve several key aspects, namely physical, institutional and economic. As for the physical aspect, several elements need to be taken into account, namely the development stage, physical design and development. As for the institutional aspect, there are several parties involved, namely the government and legitimacy, while for the economic aspect, finance, marketing and promotion are among the elements that need to be given due attention. Table 6 below is a summary of the MAINPP waqf property development process by stage: 
INTERNATIONAL JOURNAL OF ACADEMIC RESEARCH IN PROGRESSIVE EDUCATION AND

DEVELOPMENT

Vol. 10, No. 4, 2021, E-ISSN: 2226-6348 @ 2021 HRMARS

Table 6: MAINPP Waqf Property Development Process by Stage Source: (Geshwender, 2000; MAINPP, 2021)

Types of Considerations

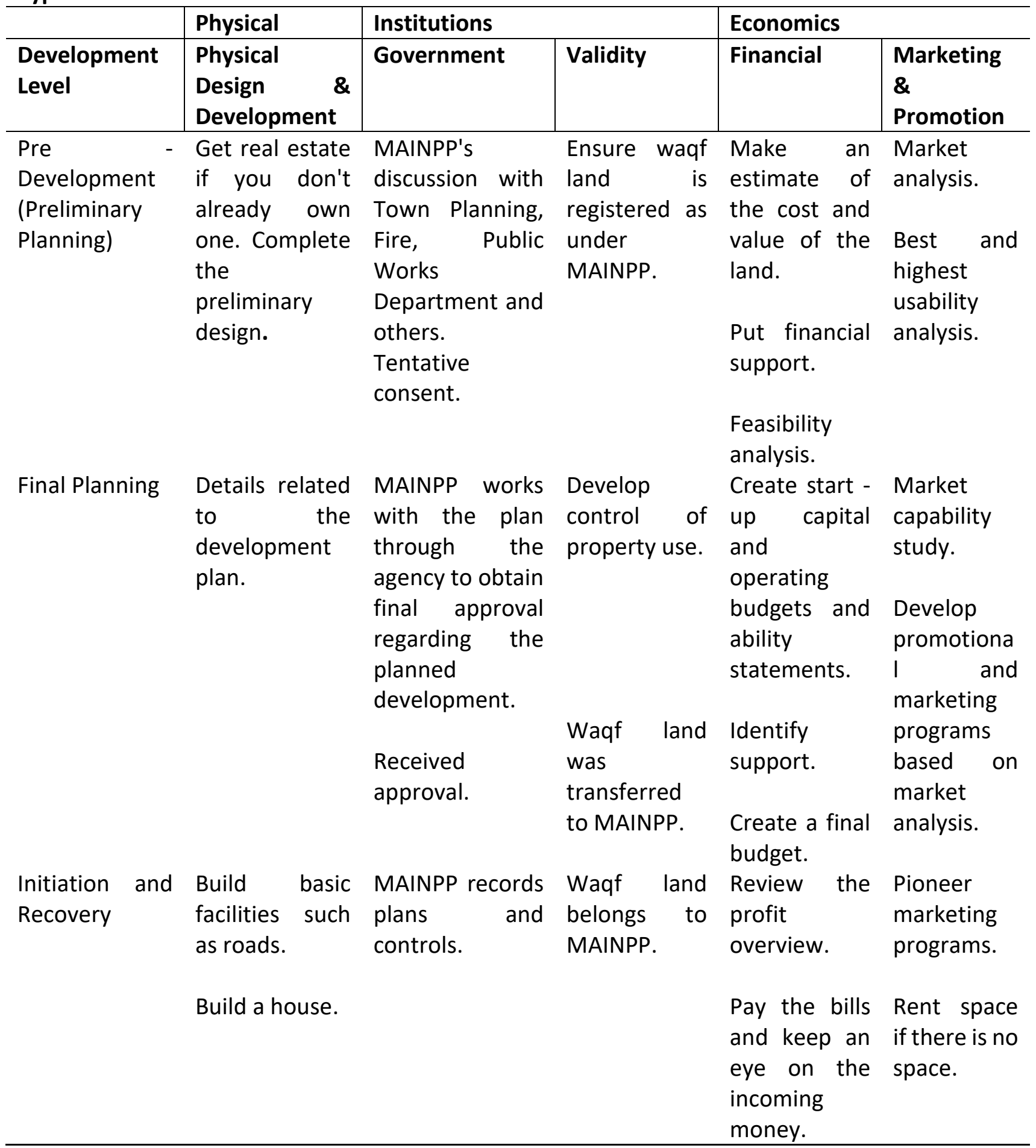

The need to analyze the land property development process is very similar to investing. A significant change in property development is the cost of the land and this includes maintenance costs. In developing waqf land, MAINPP needs to manage the maintenance and all delays must be accounted for. In addition, several important items in real estate investment such as equity risk and analytical risk should also be assessed to avoid 
future losses. In fact, the success of property development also requires a series of positive decisions implemented on the part of MAINPP as the trustee for waqf land in a project. Therefore, the need to get skilled, competent, professional and innovative managers on behalf of MAINPP is very important in developing waqf properties. All these aspects can be obtained through the concept of IWE in the development of waqf property by MAINPP.

\section{Islamic Work Ethics (IWE)}

\section{The Concept of Islamic Work Ethics (IWE)}

The origin of the word "ethics" is taken from the Greek word "ethos". "Ethos" means the character, spirit and attitude of a group of people or culture (Loeb 1971). Ethics also means a system of moral principles by which human actions can be judged as good or bad, right or wrong or recognized rules of conduct with respect to a particular class related to human actions (Oxford Dictionary, 2010). However, this term of ethics has been evaluated from a variety of different perspectives among scholars. Rachels \& Rachels (1993) stated that ethics represents a set of moral principles, rules of behaviour or values. Meanwhile, Burks (2006), argues that ethical issues arise when a person is forced to make decisions from various alternatives related to moral principles. Meanwhile, Rania (2006) formulates the term ethics in a more general context, where ethics is defined as a bond of relationship with others. Several scholars such as Elegido (2000); Delaney (2005); Ogbonna \& Ebimobowei (2011) also provide a definition of ethics according to their respective points of view. Elegido (2000) defines ethics as a mission towards an understanding of a good life, a better life and a worthwhile life. Delaney (2005) argues that ethics is concerned with the value of goodness sought in life and with rules that are supposed to govern human behaviour and interaction. Ogbonna \& Ebimobowei (2011) described ethics as what is reflected in the principles used by a person in controlling his actions and forming a standard personality by being able to distinguish between right and wrong.

Meanwhile, from the Islamic perspective, ethics can be associated with several Arabic terms such as ma'ruf, khair, haq, birr, qist, 'adl and taqwa. In Islam, all good things are known as salihat, while bad things are known as sayyi'at. However, scholars such as Beekun (1996) consider the most appropriate term for ethics in the context of the Quran to be morality (Beekun, 1996). In fact, the most important thing in ethics is how one can determine whether an action is right or wrong (Velasquez, 2006). Ethics in Islam is a noble principle and value based on Islamic sources (Mohammed, 2011). Ethics is in line with human ability (al-Ghazali, 2001) and encompasses all aspects of life (al-Qaradawi, 1994). The importance of ethics in Islam can be assessed through worship. Islamic worship is a religious deed and act commanded by Allah SWT to obtain His pleasure (Yaken, 2006), designed to improve and protect ethics (al-Banna 1940; al-Qaradawi 1985, 1994, 1996). Meanwhile, faith is a power that improves and protects ethics (al-Qaradawi 1994; Mawdudi 1977; Yaken 2006). Faith is incomplete without associating it with pious deeds (al-Ghazali 2001). This means that strong faith will generate good morals and weak faith will result in moral collapse.

\section{MAINPP Waqf Property Development Analysis Based on Islamic Work Ethics (IWE)}

Islamic Work Ethics (IWE) is a work ethic that is sourced from Islamic legal sources. Thus, some primary sources of Islamic law namely, Quran, Sunnah, ljmak, Qiyas and secondary sources such as Masalih al-Mursalah and Maqasid al-Shariah have been seen to form a better quality waqf property development management system and suitable for Islamic organizations that manage waqf like MAINPP. Among the elements of MAINPP waqf 
property development proposed according to Islamic Work Ethics (IWE) are intention, taqwa, justice, sincerity, al-Itqan (awareness for self-improvement), ihsan, trust, al-Sidq (true), shura, patience, al-Mutabaqah (compliance), ruh al-Jama'ah (team spirit) and al-Riqabah (supervision). Figure 5 is the development of MAINPP waqf properties according to IWE. Table 7 is a detail for each element of MAINPP waqf property development proposed according to IWE's perspective.

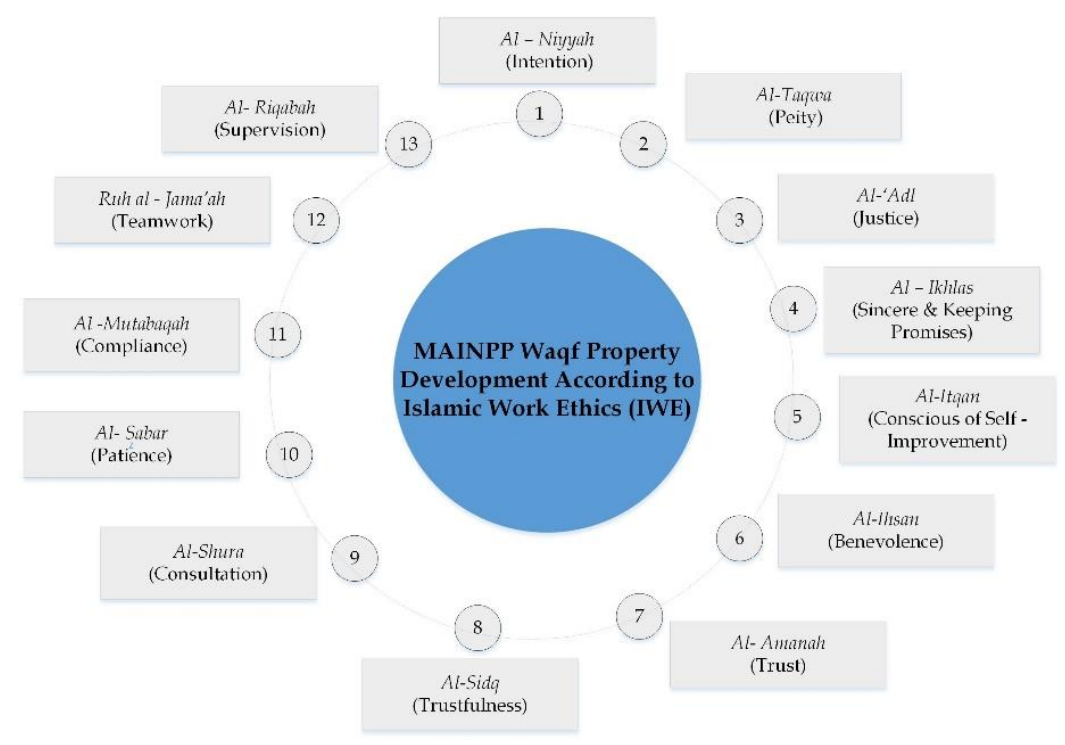

Figure 1 MAINPP Waqf Property Development According to Islamic Work Ethics (IWE) Source: Abu Bakar et al (2021) 
Table 7 Analysis of MAINPP Waqf Property Development Based on Islamic Work Ethics (IWE)

No Islamic Work Ethics (IWE)

i. Intention:

All actions of Muslims should be accompanied by the intention of doing good (Branine \& Pollard, 2010). In fact, Allah SWT will not change a person's situation unless they change what they are, as Allah SWT says: "Indeed, Allah does not change what is in a people until they change what is in themselves" (Surah Ar-Ra'd: 11). In a hadith, Rasulullah SAW said: "Indeed, every deed is based on intention and indeed everyone will follow what is intended." (Muslim History (1907)). Thus, a person needs to be judged based on his intentions.

ii. Taqwa:

Taqwa is the fear of Allah SWT because of love for Him. It is a belief that our actions and intentions are known by Allah SWT. When people only fear Allah SWT, then they will do what He commands and stay away from the deeds that He forbids by feeling the presence of Allah SWT in our actions and thought.

iii. Justice:

Justice represents absolute values and is the basic tenet of the Islamic ethical system. Under justice, all human beings should be treated equally regardless of gender, color, race, wealth, occupation or social status.
MAINPP Waqf Property Development Analysis Based on Islamic Work Ethics (IWE)

In the perspective of waqf property development, MAINPP officers who manage waqf property development should not be punished or criticized if they do not achieve the desired results of the organization. Especially, when the results that occur are due to external factors of the organization and are out of control, instead they are rewarded based on the objectives, ideas, plans, and strategies entrusted to them. This ethic will add confidence and encourage open thinking as a manager who manages waqf property development.

For MAINNPP officers who manage the development of waqf properties, it is important for them to work with full piety. This means, they will comply with the rules and standards and comply with the requirements of employment as a manager to the development of waqf property in MAINPP. Good performance will lead to good results and in turn become skills applied in MAINPP.

In developing waqf property, MAINPP must ensure that all parties who deal with it receive fair treatment, comply with sharia, rules and relevant laws (Abbasi et al, 2010). A contract that clearly describes the terms and conditions associated with the transaction, will ensure fairness in future disputes without compromising the rights of each party to the contract. Justice is also very closely related to integrity. The development of waqf property must be done fairly without denying the rights of all parties involved, namely the beneficiaries of the waqf giver, the waqf recipient, the developer and MAINPP. Development must also comply with the Maqasid Syariah which 
iv. Sincerity:

Muslims must be sincere in word and deed. Allah SWT says: "Say again:" Allah is the one I worship by sincerely practicing my religion to Him." (Surah Az-Zumar: 14).

v.-Itqan (Awareness for Self-
Improvement): Rasulullah SAW said: "Indeed, Allah SWT loves when one of you does something, he should do it diligently." (Reported by Al-Baihaqi). Based on this hadith, Islam urges its people to give their best while performing a job (Hashim, 2010). According to Branine \& Pollard (2010), itqan is to encourage self -improvement in order to perform well in the job. Itqan also leads to al-Falah which is an Islamic value in representing the spirit to excel.

vi. Ihsan:

Ihsan represents several Islamic values, such as almsgiving, perfection, goodness, forgiveness and perfect faith. However, the meaning of most benevolence is to be charitable (Branine \& Pollard, 2010). It is a voluntary act of helping others without any expectation of reward. It is also a holy act with the intention of seeking the pleasure of Allah SWT (Beekun \& Abdawi, 2005).

vii. Trust:

The Quran states: “O you who believe! Do not betray (the trust) of Allah and His Messenger, and (do not) betray your trusts while you know (the wrong)." (Surah Al-Anfal: 27). Allah SWT also said: "Yusuf said: Make me the manager of the treasury of the earth (Egypt); indeed I am covers the care of the main things, namely life, religion, intellect, lineage and property. The nature of fairness that exists in oneself will make MAINPP officers responsible for every development action taken.

The best ethic for an employee that can be given to his organization is to carry out the task with sincerity (Abbasi et al, 2010). The same goes for MAINPP as the waqf property development manager. Sincere MAINPP officers do not need constant supervision because there is an attitude of self supervision in performing their duties in a complete manner. Sincerity is also closely related to honesty.

To implement successful real estate development, skills and knowledge are essential. It also cannot be obtained unless MAINPP officers have awareness and want to improve themselves. MAINPP needs to receive feedback from others openly because it is also a reflection of their own feedback and performance. Based on the feedback, MAINPP should be open and work in a better direction.

Consistent with Ali's (1988) view, ihsan shapes individual and group interactions in organizations as well as equips employees with values such as forgiveness, compassion, kindness, tolerance and kindness. For MAINPP, all of these values are very important, especially in relation to relationships with other employees in the organization.

Trust is important in the waqf property development process and is able to accelerate the performance and cooperation between MAINPP and the developer. Reliable and trustworthy effects will influence the level of good performance. MAINPP as a religious institution needs to feel safe to open up and show its strengths 
ready to take care of it as best I can, and know how to administer it." (Surah Yusuf: 55). These two sentences clearly reflect the importance of trust in management. The value of trust is also represented by the story of Prophet Moses AS, as in the words of Allah SWT: "One of the two women said: "O father, take him to be a hired man (herding our goats), indeed the best person whom you take to work is a strong man, yet trustworthy." (Surah AlQasas: 26).

viii. Al-Sidq (Truth):

Al-Sidq refers to doing and saying what is true and what is contrary to al-Sidq is lying or deceiving (Branine \& Pollard, 2010). Islam does not recognize an individual for being honest in one aspect of his life and at the same time lying in another aspect. Muslims must keep their promises. Breaking a promise is also not Islamic behavior, especially if it is done intentionally (Abuznaid, 2006).

ix. Shura:

Islam emphasizes the importance of seeking advice. This is stated in the Quran: "... and their affairs are conducted in consultation with each other." (AsySyura: 38). Rasulullah SAW also practiced consultation or shura with his companions before making decisions in different matters.

x. Patience:

Patience is an important ethical value in Islamic teachings. Patience is practiced in two ways, namely mental and physical. Patience in the mental aspect is the ability to control one's anger. Patience in the physical aspect is represented by tolerance of physical pain, doing worship and weaknesses without fear of the parties who want to collaborate with them. This transparency and trust is important for the successful development of waqf properties.

Fulfilling the promises made between MAINPP, the developer and the contracting parties can increase confidence in quality and create a culture of trust (Branine \& Pollard, 2010). Abbasi et al. (2010) regard trust as an important ethical value in Islam because it involves speech, intention, determination and fulfillment of actions for all paths of Islamic work ethic. In activities related to waqf property development, alSidq is able to build confidence among all stakeholders.

Shura is one of the main features of the management of Rasulullah SAW. Therefore, MAINPP is encouraged to consult with various parties before making a decision, (Branine \& Pollard, 2010). The shura process can help in developing consensus and agreement by ensuring that all decisions made can benefit all parties. In addition, shura can also encourage humility in the task of managing development and involve various parties with each other in the decision -making process (Abuznaid, 2006)

Managers who manage waqf property development must be able to control their emotions in the process of managing development. Among the attitudes that MAINPP officers need to have is to be able to face difficulties and be ready to serve the organization well. Patience is one of the aspects of diplomacy in the process of staged development of waqf property. 


\section{DEVELOPMENT}

Vol. 10, No. 4, 2021, E-ISSN: 2226-6348 @ 2021 HRMARS

or facing difficulties in life (Abbasi et al, 2010).

xi. Al-Mutabaqah (Compliance):

In Islam, compliance is considered among the criteria for achieving quality of performance. For example, the pillars of Islam and Iman which are the basic elements of the Islamic faith and must be observed by every Muslim. Therefore, any deviation from these elements is considered inconsistent with God's law and His rules. The rules for compliance also apply to the activities of Muslims in the community and work environment, including the development of waf properties which should also comply with Islamic principles.

xii. Ruh al-Jama'ah (Team Spirit):

Islam emphasizes the need to work in a team and directs all efforts towards achieving group objectives and values. The encouragement of this teamwork can be seen in the words of Allah SWT: "And hold fast, all of you, to the rope of Allah (Islam), and do not be divided..." (Surah 'Ali-'Imran: 103).

xiii. Al-Riqabah (Supervision):

Allah SWT said: "There is no word that he utters (or deeds that he does) unless there is by his side a guardian angel who is always ready (to receive and write it)." (Surah Qaaf: 18). Everything said and done by a Muslim will be noticed by Allah. Islam emphasizes the importance of supervision, where, as the manager who manages the development of waqf properties, MAINPP is not only responsible for carrying out the development alone but the development done must comply with Islamic principles as well.
Compliance in waqf property development means being professional in carrying out the job. All laws, fatwas and regulations must be complied with by MAINPP. In addition, MAINPP should also consider some good standards to be used as a reference in the development process. Continuous learning and evaluation is essential to make positive decisions in developing waqf properties.

For waqf property development, it is important for MAINPP to share the same values and work objectives, together as a team (Abbasi et al, 2010). This ethic is one of the skills that need to be nurtured in MAINPP.

Islamic control either internally or externally will lead to the implementation of the goals set by Islamic law and MAINPP. MAINPP officers need to be guided, trained and evaluated and ultimately act on decisions and suggestions towards improvement. It is a prerequisite to a holistic development ecosystem of waqf properties. The monitoring process can also take place in waqf property investment, that is, by measuring the investment capacity of waqf property, so that future and ongoing investments will be able to bring the maximum return in accordance with Islamic law and the concept of sustainable waqf. 


\section{Conclusion}

In conclusion, the development of waqf properties in MAINPP has undergone various dramatic changes over the centuries. MAINPP as the sole trustee of waqf property in the state of Penang always works hard in developing waqf lands for the benefit of Muslims in the state. The waqf property development process involves various activities to manage MAINPP's physical and financial resources as well as expertise in developing land to revenue-generating resources. It is recommended that MAINPP adopt Islamic Work Ethics (IWE) which emphasizes elements such as intention, taqwa, justice, sincerity, al-Itqan (awareness for selfimprovement), ihsan, trust, al-Sidq (truth), shura, patience, al-Mutabaqah (compliance), ruh al-Jama'ah (team spirit) and al-Riqabah (supervision) in developing waqf properties in the state of Penang towards a more productive and sustainable.

\section{Acknowledgement}

This research was funded by the Sultan Abdul Halim Mu'adzam Shah International Islamic University (UniSHAMS) under the Short-Term Grant Phase 5/2020

(UniSHAMS/STGRMU/2020).

\section{References}

Al-Qur'an al-Karim.

Abbasi, A. S., Kashif, U. R., \& Bibi, A. (2010). Islamic Management Model. African Journal of Business Management 4(9): 1873-1882.

Abu Bakar, M., Ismail, S., Ismail, C. Z., \& Ramli, N. A. (2021) Isu-Isu dan Cabaran Pembangunan Hartanah Wakaf di Majlis Agama Islam Negeri Pulau Pinang (MAINPP). Kuala Ketil: Universiti Islam Antarabangsa Sultan Abdul Halim Mu'adzam Shah (UniSHAMS) Sdn. Bhd.

Abuznaid, S. (2006). Islam and Management: What Can Be Learned? Thunderbird International Business Review 48, 125-139.

Akta Kanun Tanah Negara 1965.

Ali, A. (1988). Scaling an Islamic Work Ethic. Journal of Social Psychology 128(5), 575-583.

Al-Ansari, J. M. t.t. Lisan al-Arab. Mesir: Dar al-Masriyah.

Al-Muslim. t.t. Sahih al-Muslim. T.tp: Dar al-Fikr.

Al-Banna. (1940). Messages' Group of Imam Hasan al-Banna. (1st ed.). Alexandria: Darul AlD'aoah Publication.

Al-Ghazali. (2001). Muslim's Morality. (16th ed.). Beirut: Darul Al-Qalam Publication.

Al-Syarbini, M. A. (1933). Mughni al-Muhtaj. Juz 2. Mesir: Mustafa al-Babi al-Halabi

Al-Khin, M., Al-Bugha, M., \& al-Syarbaji, A. (2003). Kitab Fikah Mazhab Syafie. Terj. Solehan Ayub. Kuala Lumpur: Pustaka Salam.

Al-Qaradawi, Y. (1985). The Iman (Faith) and Life. Doha: Arabia Publication. www.daawainfo.net [Dicapai pada 15 November 2021].

Al-Qaradawi, Y. (1994). The Priorities of Understanding. Beirut: Darul Al-Ressalh Publication. www.fiseb.com [Dicapai pada 15 November 2021].

Al-Qaradawi, Y. (1996). The General Characteristics of Islam. (9th ed.). Beirut: Darul Al-Ressalh Publication.

Al-Qurtubi, Y. A. (1980). Kitab al-Kafi fi Ahl al-Madinah al-Maliki. Juz 2. Riyadh: Maktabah alRiyadh al-Hadithah.

Beekun, R. (1996). Islamic Business Ethics. Nevada: University of Nevada.

Beekun, R. I., \& Badawi, J. A. (1999). Leadership: An Islamic perspective. Beltsville, MD: Amana. 
Branine, M., \& Pollard, D. (2010). Human Resource Management with Islamic Management Principles: A Dialectic for a Reverse Diffusion in Management. Personnel Review 39(6), 712- 727.

Burks, B. (2006). The Impact of Ethics Education and Religiosity on the Cognitive Moral Development of Senior Accounting and Business Students in Higher Education. Unpublished doctoral thesis. Nova Southeastern University, USA.

Covey, S. M. R. (2006). The Speed of Trust. Free Press, New York, NY.

Delaney, J. (2005). The Impact of Ethics Education on the Moral Reasoning Ability of Accounting Students. Unpublished doctoral thesis. Ambrose University, USA.

Elegido, J. M. (2000). Fundamental of Business Ethics: A Developing Countries Perspective. Lagos: Spectrum Books Ltd.

Enakmen Pentadbiran Agama Islam (Negeri Pulau Pinang) 2004. Enakmen Undang-Undang Pentadbiran Agama Islam 1959.

Geschwender, A. (2000). Real Estate Principles and Practices. (6th Edition). New Jersey: Prentice Hall.

Hashim, J. (2010). Human resource management practices on organisational commitment: The Islamic perspective. Personnel Review 39(6):785-799.

Ibn 'Abidin, M. A. (1966). Hashiah Radd al-Mukhtar. Juz 4. Mesir: Mustafa al-Babi al-Halabi.

Ismail, C. Z., Bakar, M. A., Ismail, S., \& Ramli, N. A. (2021). Kapitan keling waqf land development: Issues and challenges. Linguistics and Culture Review, 5(S2), 1184-1196.

Ismail, S., Bakar, M. A., Ismail, C. Z., \& Ramli, N. A. (2021). Issues and challenges in wakaf seetee aishah property development, Penang state Islamic religious council (MAINPP). Linguistics and Culture Review, 5(S3), 1111-1123.

Jabatan Kemajuan Islam Malaysia (JAKIM). 2000. Himpunan Keputusan Muzakarah Jawatankuasa Fatwa Kebangsaan, Berhubung Dengan Isu-Isu Muamalat. Putrajaya: JAKIM.

Kamus Oxford. (2010). Oxford Dictionary of English. 3rd Revised edition. Oxford University Press: Oxford, United Kingdom.

Loeb, S. (1971). A Survey of Ethical Behaviour in the Accounting Profession. Journal of Accounting Research 9(2): 287-306.

Mahamood, S. M. (2001). Bagaimana Membuat Wakaf: Siri Penerangan Undang-Undang Islam. Kuala Lumpur: Akademi Pengajian Islam, Universiti Malaya.

Majlis Agama Islam Negeri Pulau Pinang (MAINPP). (2020). Portal Rasmi MAINPP. https://www.mainpp.gov.my/ [Dicapai pada 12 November 2021].

Majlis Agama Islam Negeri Pulau Pinang (MAINPP). 2021. Fail Data Maklumat MAINPP. Mawdudi. (1977). Life's System in Islam. (7th ed.). Beirut: Darul Al-Ressalh Publication.

Mohammed, A. (2011). The Role of Yemeni Accountants in Fighting Corruption. The Legal Accountant 15(9): 30-37.

Roslan, M. S. F. (2017). Pembangunan Tanah Wakaf di Pulau Pinang: Masalah dan Penilaian Strategi. Latihan Ilmiah. Ijazah Sarjana Muda Sains Pembinaan. Fakulit Alam Bina: Universiti Teknologi Malaysia.

Mustafa, E. M. A. (2015). Impact of Total Quality Management Practices on Innovation in Service Organizations. Tesis Doktor Falsafah. Universiti Tun Hussein Onn Malaysia.

Ogbonna, G., \& Ebimobowei, A. (2011). Ethical Compliance by the Accountant on the Quality of Financial Reporting and Performance of Quoted Companies in Nigeria. Asian Journal of Business Management 3(3): 152-160. 
Osman, S., \& Shafie, S. (2006). Asas Pengurusan Harta Tanah. Sintok: Penerbit Universiti Utara Malaysia.

Rachels, J., \& Rachels, S. (1993). The Elements of Moral Philosophy. New York: McGraw-Hill. Rania, A. (2006). Business Ethics as Ethics as Competitive Advantage for Companies in the Globalization Era. New York: Social Science Research Network.

Sayyin, B., Ali, A., \& Suyorno, S. S. (2006). Pengenalan Pengurusan Wakaf di Malaysia. Shah Alam: Pusat Penerbitan Universiti Teknologi MARA.

Velasquez, M. (2006). Business Ethics: Concepts \& Cases. (6th ed.). London: Person Education International.

Yaken. (2006). What is the Meaning of My Belong to Islam? Beirut: Darul Al-Ressalh Publication. 